\title{
NATIONAL HEALTH INSURANCE - IMPLICATIONS FOR REHABILITATION PROFESSIONALS AND SERVICE DELIVERY
}

\begin{abstract}
This paper reviews the National Health Insurance (NHI) in view of what is proposed and authors suggest how it may impact on the rehabilitation sector namely occupational therapy, physiotherapy, speech and language therapy and audiology. A review of the basic description of the NHI and the different elements is presented. Particular attention is paid to how much interface and mention is made of rehabilitation. The current status of rehabilitation service provision and its response to the needs of the population, in particular the burden of disease and the related finance models are discussed. Suggestions are presented for the way forward to ensure rehabilitation professionals and services rendered are not caught flat footed.
\end{abstract}

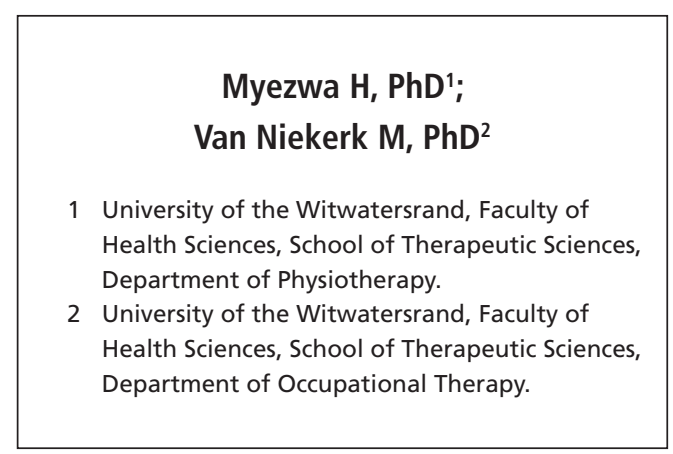

Van Niekerk M, PhD

University of the Witwatersrand, Faculty of Health Sciences, School of Therapeutic Sciences, artment of Physiotherapy. Department of Occupational Therapy.

KEY WORDS: NATIONAL HEALTH INSURANCE, REHABILITATION, IMPLICATIONS, OCCUPATIONAL THERAPY, PHYSIOTHERAPY.

\section{INTRODUCTION}

The motivation for National Health Insurance (NHI) is driven by the inequalities that exist in the provision of health in South Africa (Department of Health 2011a). The NHI is in its early phase of development and rehabilitation professionals need to engage and respond proactively. An important starting point is to examine the full intent of the NHI.

Our objectives have several dimensions: 1) To examine and assess the National Health Insurance (NHI) and the points at which it addresses rehabilitation issues. 2) Identify gaps in the NHI pertinent to rehabilitation. 3) Analyze our current situation in terms of staffing service delivery and response to current needs. 4) Provide recommendations for inclusion of rehabilitation services

\section{Correspondence Author:}

Dr Hellen Myezwa

Department of Physiotherapy,

Faculty of Health Sciences,

University of the Witwatersrand

Johannesburg, South Africa

Email: hellen.myezwa@wits.ac.za

Van.niekerk@wits.ac.za within the NHI. Epidemiological data to inform rehabilitation service is in its infancy (Jelsma et al 2002) and therefore we acknowledge the lack of cohesive data for rehabilitation.

\section{REVIEW OF THE NHI}

The green paper on the NHI outlines the allocation of resources to heath care delivery and how it is at odds with the quality of care provided. A comparison of the percentage of Gross Domestic Product (GDP) spent on health care shows that SA exceeds the WHO recommended level of expenditure (Department of Health 2011a). In spite of this, expenditure for health in South Africa is still inverted with $16 \%$ of the population having $4.1 \%$ of the GDP spent on their health needs while an almost equal percentage of GDP is spent on $84 \%$ of the country's population, as illustrated by Figure 1.

An interesting historical perspective found in the NHI Green Paper is that the proposals to reform the model to finance

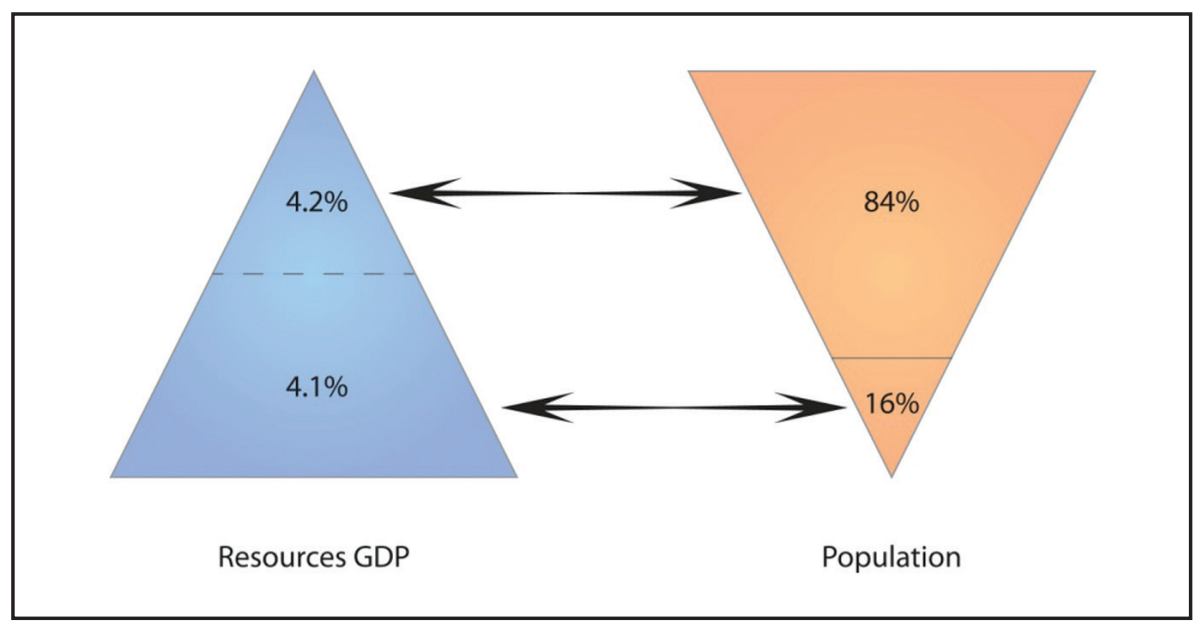

Figure 1: Resources versus population distribution 
health systems is not a new phenomena and has its roots as early as 1928 with a commission on old age pension and national insurance. Subsequent efforts included a committee of enquiry into National Health Insurance (1935), the Gluckman commission 1942-1944. Two committees in 1994 and 1995 respectively investigated reforms in healthcare funding, which were followed by various inquiries into social health insurance between 1997 and 2002 (DOH 2011a). Finally, a Ministerial advisory committee on national health insurance was established, which made recommendations regarding reforms to the healthcare system, effectively implementing Resolution 53 made at the ANC's 2007 Polokwane Conference (ANC 2010). This was the first time that the work of a commission or committee resulted in implementation of a plan to address the inequities in health care service delivery. The NHI's main aim is to improve access to health. It further aims to subsidise people, across the different population groups, who cannot afford health care and links contributions to the scheme to people's ability to pay. It also aims to procure services on behalf of the populace and to improve and rehabilitate the public health system.

Prioritising health interventions and staffing is based on the country's health needs, as expressed by the burden of disease. The NHI green paper emphasises that the public health sector services the bulk of the population, and carries the greatest burden of disease (Department of Health 2011a). Burden of disease relates to information about the mortality, morbidity, injuries, disabilities and related risk factors (Econex 2009) and provides important information for health planning to address any persistent gaps to ensure better health for the population (Bradshaw et al 2003). The NHI aims to achieve this by establishing a committed, accountable and skilled force of health care workers, ensuring sustainable and equitable access to health care for all in South Africa (emphasising community-based promotion and prevention services), and ensuring responsible leadership (Kleinert \& Horton 2009:760; Matsotso et al 2013:1).
Burden of disease information is based on three figures: years of life lost due to premature death (YLLs) and years of life lived with disability (-ies) (YLDs). When combined, these figures form the disability-adjusted life year (DALY) (Bradshaw et al 2003:682; Econex 2009:1) which is indicative of non-lethal health outcomes and premature death (Jelsma et al 2002). Globally, the burden of disease is presented in terms of three categories of conditions: 1) pre-transitional causes of death, including communicable diseases, maternal conditions, prenatal condition and nutritional deficits, 2) non-communicable conditions (e.g. diseases of lifestyle such as hypertension and diabetes) and 3) injuries. In global analyses, HIV/AIDS and tuberculosis form part of the first group, as they are communicable diseases. In South Africa, however, their contribution to the burden of disease is so significant that the data are kept separate, giving South Africa a quadruple burden of disease (Bradshaw et al 2003). The most recent figures on the quadruple burden of disease, published by the Medical Research Council's ( MRC) Burden of Disease Research Unit published 2006, as interpreted by Econex 2009, can be seen in Figure 2.

Many of the guiding principles of NHI are similar to those of Primary Health Care (PHC) and include the right to access, social solidarity, effectiveness, appropriateness, equity, affordability and efficiency. As such, the NHI has undertaken to review and strengthen the PHC system i.e. Primary Health Care re-engineering which includes systems strengthening.

The systems for service delivery that have been targeted are the district, school based PHC services and the municipal ward based service. Delivery of services within these streams involves distinct proposed approaches such as strengthening administrative systems, cost effective interventions with adequate professional staff, ethical service delivery, adhering to set quality standards and adherence to clinical guidelines.

Public and private partnership linkages are proposed to enhance service delivery. Provision of service by contracted private practitioners and models to provide services may be through defining a selected number of services at primary and hospital care. Rehabilitation is mentioned in the provision of services only under the district hospital. It is seemingly not embedded in the description of services anywhere else but mentioned under the definition of health benefits, the discussion on underfunding, the use of pooled resources and in the definition of universal coverage. However, including rehabilitation at the appropriate service-delivery levels (e.g. PHC level and hospital settings) is important, as reference to this document for implementation by policy makers will

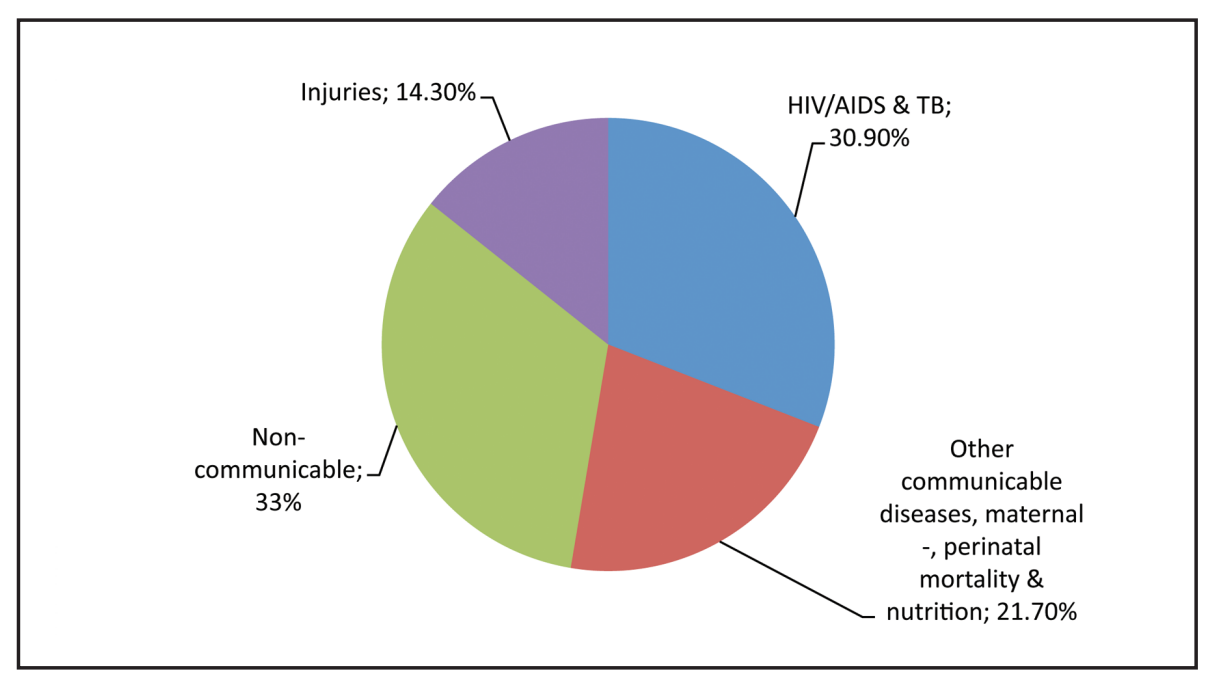

Figure 2: Estimated DALYs per Category for South Africa, 2000, from Econex 2009:2 
result in deliberate inclusion. Many of the heath system concerns covered in the NHI policy documents can be applied to rehabilitation service delivery issues. Importantly, figures obtained from the National Department of Health (NDoH)(Department of Health 2010) indicate a low percentage of therapists employed by the NDoH, as illustrated in Table 1.

Figures reported in the Human Resource plan for Health show a steady increase in the employment of members of all three professions in the $\mathrm{NDoH}$ from 2003 to 2010 (Department of Health October 2011). While the employment of physiotherapists and speech therapists and audiologists continued to increase from 2010 to 2012 , there is a decline in the employment of occupational therapists, dropping from 837 in 2010 to 794 in 2012. Despite the decline in the employment of occupational therapists between 2010 and 2012, overall there is still an increase in employment between 2003 and 2012 - from 531 in 2003 to 794 in 2012. Employment of physiotherapists in the $\mathrm{NDoH}$ increased significantly from 617 in 2003 to 1040 in 2012. The ratio of health workers across the board to 100000 population is not optimal with physiotherapists at a ratio of 12 and occupational therapists 7 (HST 2013). The same could be said of the ratio of doctors and nurses to patients, which although better stands at 55 doctors and 361 nurses to 100000 (DoH 2011). Across all professions discrepancies exist across public and private, urban and rural and across types of service (George et al 2012). It has been pointed out that the debate around human resources should not be reduced to one of numerical shortage but should extend to appropriate use of the existing personnel (George 2012).

In order for the rehabilitation professions to remain relevant, they need to address the burden of disease, which reflects the demands for health care (Econex 2009). In order to ensure effective service delivery, staffing and the supply of health care services should relate with the need as expressed by the DALYs (Econex 2009).

The MRC-study highlighted the top 20 contributors to South Africa's burden

Table 1: Employment figures of selected rehabilitation professions in NDoH as at March 2012

\begin{tabular}{|l|c|c|c|}
\hline & $\begin{array}{c}\text { Occupational } \\
\text { therapy- } \\
\text { OT }\end{array}$ & $\begin{array}{c}\text { Physiotherapy- } \\
\text { PT }\end{array}$ & $\begin{array}{c}\text { Speech language } \\
\text { and hearing } \\
\text { SLT (includes } \\
\text { single registered } \\
\text { practitioners) }\end{array}$ \\
\hline $\begin{array}{l}\text { Registered with } \\
\text { HPCSA }\end{array}$ & 3861 & 6162 & 2267 \\
\hline Employed by NDoH & 794 & 1040 & 403 \\
\hline $\begin{array}{l}\text { Percentage } \\
\text { employed in NDoH }\end{array}$ & $20.56 \%$ & $16.88 \%$ & $17.78 \%$ \\
\hline
\end{tabular}

Table 2: Revised estimates of DALYs for South Africa, 2000, adapted from Norman et al 2006:22 (Norman et al 2006)

\begin{tabular}{|c|c|c|}
\hline Rank & Cause & Percentage \\
\hline 1 & HIVIAIDS & 30.9 \\
\hline 2 & Interpersonal violence & 6.5 \\
\hline 3 & Tuberculosis & 3.7 \\
\hline 4 & Road traffic accidents & 3.0 \\
\hline 5 & Diarrhoeal diseases & 2.9 \\
\hline 6 & Lower respiratory infections & 2.8 \\
\hline 7 & Low birth weight & 2.6 \\
\hline 8 & Asthma & 2.2 \\
\hline 9 & Stroke & 2.2 \\
\hline 10 & Unipolar depressive disorders & 2.0 \\
\hline 11 & Ischaemic heart disease & 1.8 \\
\hline 12 & Protein-energy malnutrition & 1.3 \\
\hline 13 & Birth asphyxia and birth trauma & 1.2 \\
\hline 14 & Diabetes mellitus & 1.1 \\
\hline 15 & Alcohol dependence & 1.0 \\
\hline 16 & Hearing loss, adult onset & 1.0 \\
\hline 17 & Cataracts & 0.9 \\
\hline 18 & Hypertensive heart disease & 0.9 \\
\hline 19 & Fires & 0.9 \\
\hline 20 & Falls & 0.9 \\
\hline
\end{tabular}

of disease in terms of disability-adjusted life years as expressed in Table 2.

Figures based on DALYs are important to therapists as these figures are indicative of the need for rehabilitation in a country's population.

\section{CURRENT RESPONSE TO REHABILI- TATION NEEDS}

Two methods have been used to assess the current rehabilitation response to health needs, namely: an assessment of published papers in the local journals and an analysis of the common conditions seen by therapists. The pattern of publications represents by proxy the current focus of demand, service delivery and research within the professions, while conditions that are captured in statistics will reflect professional activity. Arksey and O'Malley (2005:2122 ) indicated that rapid review of the 
literature is important as it provides information at a glance to amongst others, policy makers.

Three studies assessing publications to show the focus for research in physiotherapy have been published (Mothabeng 2003; Mothabeng 2006; Frantz et al 2011). Two of these studies assessed the relevancy of the papers to the country's needs. The authors concluded that there is some relevancy to the country's needs. Mothabeng (2003, 2006) identified gaps such as HIV, health promotion and human resources which in the later review (Frantz et al 2011) reflected progress. Though the bulk of the research was in clinical practice areas, 60\% in 2002 and 45\% in the period 1989-2003 the author did not give detail on the type of conditions covered. Between 2002-2010 the most published clinical areas were musculoskeletal (47), education (17), chronic lifestyle diseases (15), neurology (15), cardiopulmonary (13) followed by communicable disease (11) (117 of 170 69\%) (Frantz et al 2011). Similarly, an overview of papers published between 2003 and 2012 in the South African Journal of Occupational Therapy shows that development-related interventions in childhood is the topic of most papers (17 of 136 papers) with mental healthrelated conditions second (12 of 136 articles). There were two papers on HIV/AIDS during this period.

Tables 3 and 4 outline the conditions seen in Gauteng within all the physiotherapy departments. No national figures are available and similar figures are not available for the other professions.

While it is not possible to accurately link the information obtained from the journal articles or the $\mathrm{NDoH}$ to the country's burden of disease because these sources do not relate the information to the cause of the conditions, it can be extrapolated that physiotherapists already address some conditions that relate to the burden of disease. Some conditions treated by physiotherapists, such as head injuries can easily be assumed to fall within the category of injuries. With the current data collection methods, other conditions are not as easily classified. For example, ICU conditions, which could be the result of injury, HIV/AIDSrelated complications, communicable, and non-communicable diseases.

Table 3: Conditions seen in Gauteng hospitals2005-2011 by physiotherapists.

\begin{tabular}{|c|c|c|c|c|c|c|c|}
\hline & 2005 & 2006 & 2007 & 2008 & 2009 & 2010 & 2011 \\
\hline & $n(\%)$ & $n(\%)$ & $n(\%)$ & $n(\%)$ & $n(\%)$ & $n(\%)$ & $n(\%)$ \\
\hline ICU conditions & 1699 (3.68) & 2376 (3.79) & $3289(4.60)$ & $3708(4.55)$ & $3624(4.56)$ & 5791(4.25) & $5730(5.49)$ \\
\hline Hands & $1883(4.08)$ & $2980(4.76)$ & $2881(4.03)$ & $2490(3.06)$ & $3236(4.07)$ & $\mathrm{n} / \mathrm{d}$ & $n / d$ \\
\hline $\begin{array}{l}\text { COPD/chronic } \\
\text { lungs }\end{array}$ & $1994(4.32)$ & $2792(4.46)$ & $n / d$ & $3376(4.15)$ & $3852(4.85)$ & $\mathrm{n} / \mathrm{d}$ & $n / d$ \\
\hline $\begin{array}{l}\text { Amputations: } \\
\text { Vascular }\end{array}$ & 2099(4.54) & $2912(4.65)$ & 2908(4.07) & $2645(3.25)$ & $2641(3.32)$ & $\mathrm{n} / \mathrm{d}$ & $n / d$ \\
\hline Head Injuries & $2306(4.99)$ & $2855(4.56)$ & $3121(4.37)$ & $3061(3.76)$ & 2993(3.77) & $\mathrm{n} / \mathrm{d}$ & $n / d$ \\
\hline Laringectomy & $2661(5.76)$ & $3929(6.27)$ & $n / d$ & $n / d$ & $\mathrm{n} / \mathrm{d}$ & $\mathrm{n} / \mathrm{d}$ & $n / d$ \\
\hline $\begin{array}{l}\text { Neck } \\
\text { (Discogenic } \\
\text { Lesions) }\end{array}$ & $3260(7.06)$ & $3794(6.06)$ & $4311(6.03)$ & $4518(5.55)$ & 4284(5.39) & $5467(4.01)$ & \\
\hline Cerebral Palsy & $3469(7.51)$ & $3850(6.14)$ & $4446(6.22)$ & $4705(5.78)$ & $4940(6.22)$ & $4971(3.65)$ & $3524(3.38)$ \\
\hline $\begin{array}{l}\text { Soft Tissue } \\
\text { Injuries }\end{array}$ & $3881(8.40)$ & $4384(7.00)$ & $5298(7.41)$ & $6001(7.37)$ & $5557(6.99)$ & $7969(5.84)$ & $5679(5.45)$ \\
\hline $\begin{array}{l}\text { Cerebral } \\
\text { Vascular } \\
\text { Incidents }\end{array}$ & 4199(9.09) & $6022(9.61)$ & $8312(11.63)$ & $7562(9.29)$ & $7478(9.41)$ & $9424(6.91)$ & $6429(6.16)$ \\
\hline $\begin{array}{l}\text { Soft Tissue } \\
\text { Reconstructive } \\
\text { Surgery }\end{array}$ & $4636(10.03)$ & 7193(11.48) & $6385(8.93)$ & $5489(6.74)$ & $5136(6.46)$ & $\mathrm{n} / \mathrm{d}$ & $n / d$ \\
\hline $\begin{array}{l}\text { Brachial Plexus } \\
\text { injuries }\end{array}$ & $4694(10.16)$ & $6596(10.53)$ & $7558(10.57)$ & $7482(9.19)$ & $7155(9.00)$ & $\mathrm{n} / \mathrm{d}$ & $n / d$ \\
\hline Transplants & $6323(13.68)$ & $8181(13.06)$ & $5276(7.38)$ & $4054(4.98)$ & $3452(4.34)$ & $\mathrm{n} / \mathrm{d}$ & $\mathrm{n} / \mathrm{d}$ \\
\hline
\end{tabular}


The overview of the publications in the South African Journal of Occupational Therapy (SAJOT) shows that occupational therapists address some conditions related to the burden of disease. However, in the absence of data related to the actual numbers of occupational therapists working in the different fields of practice of the profession, it is not possible to evaluate whether these publications are reflective of the profession. It appears that the statistics kept by hospital departments and other institutions, such as the Health Professions Council of South Africa HPCSA, do not enable researchers to relate such statistics to the country's burden of disease. The way in which statistical data is kept requires reorganisation to determine realistic evaluation of service delivery in the NHI and private contexts.

\section{WHAT IS THE CURRENT RESPONSE TO THE NHI AND WHAT DOES IT MEAN FOR REHABILITATION?}

Two major factors are evident from the analysis done using key elements identified in the PHC reengineering efforts, namely discrepancies in rehabilitation service delivery and a poorly structured information system (which appears worse in OT than PT). Despite the dearth of similar statistical information for all three professions, the gaps have been assessed using the response to burden of disease, personnel needs, approaches to service delivery at both a broad level (how the service is structured e.g. CBR vs. institution) and more specifically how patients receive service at the point of contact with health professionals. The type of service will be distinguished based on whether the patient gets his service in one place (supermarket approach) or his has to move from professional to professional (service in silos). Therapists are seeing a wide range of conditions that represent the quadruple burden of disease. Based on the statistics assessed in Gauteng DoH the type of rehabilitation information collected is currently malaligned with burden of disease data and could be improved.

The availability of therapists remains a challenge to service delivery. In relation to systems and improvement of management as outlined in the NHI document, Bateman (2012) interviewed therapists working in rural areas. Some of the practical difficulties for rehabilitation included: in-patients referred to hospitals and not receiving attention, no allocation of transport to rehabilitation, premature discharge without therapy leading to complications

Table 4: Conditions seen by Physiotherapists by category 2005-2011 (Source of data: NdoH - statistics project 2013)

\begin{tabular}{|c|c|c|c|c|c|c|c|}
\hline \multirow[b]{2}{*}{ Conditions } & \multicolumn{7}{|c|}{ Year and annual figures and percentages } \\
\hline & $\begin{array}{l}2005 \\
n \\
(\%)\end{array}$ & $\begin{array}{l}2006 \\
n \\
(\%)\end{array}$ & $\begin{array}{l}2007 \\
\text { n } \\
\text { (\%) }\end{array}$ & $\begin{array}{l}2008 \\
n \\
(\%)\end{array}$ & $\begin{array}{l}2009 \\
n \\
(\%)\end{array}$ & $\begin{array}{l}2010 \\
n \\
(\%)\end{array}$ & $\begin{array}{l}2011 \\
n \\
(\%)\end{array}$ \\
\hline Ortho & $\begin{array}{l}24196 \\
(52.36)\end{array}$ & $\begin{array}{l}32443 \\
(51.78)\end{array}$ & $\begin{array}{l}36609 \\
(51.22)\end{array}$ & $\begin{array}{l}38224 \\
(46.93)\end{array}$ & $\begin{array}{l}36297 \\
(45.67)\end{array}$ & $\begin{array}{l}50463 \\
(37.01)\end{array}$ & $\begin{array}{l}39845 \\
(38.21)\end{array}$ \\
\hline Respiratory & $\begin{array}{l}16285 \\
(35.240\end{array}$ & $\begin{array}{l}21896 \\
(34.95)\end{array}$ & $\begin{array}{l}26176 \\
(36.62)\end{array}$ & $\begin{array}{l}33702 \\
(41.38)\end{array}$ & $\begin{array}{l}33818 \\
(42.55)\end{array}$ & $\begin{array}{l}20985 \\
(15.39)\end{array}$ & $\begin{array}{l}16499 \\
(38.2) 1\end{array}$ \\
\hline Neuro & $\begin{array}{l}14832 \\
(32.10)\end{array}$ & $\begin{array}{l}18744 \\
(29.92)\end{array}$ & $\begin{array}{l}24829 \\
(34.74)\end{array}$ & $\begin{array}{l}25331 \\
(31.10)\end{array}$ & $\begin{array}{l}25512 \\
(32.10)\end{array}$ & $\begin{array}{l}31519 \\
(23.11)\end{array}$ & $\begin{array}{l}23290 \\
(22.33)\end{array}$ \\
\hline Women's health & $(0.00)$ & $(0.00)$ & $(0.00)$ & $(0.00)$ & $(0.00)$ & $\begin{array}{l}5566 \\
(4.08)\end{array}$ & $\begin{array}{l}2891 \\
(2.77)\end{array}$ \\
\hline $\begin{array}{l}\text { Other ( ICU, burns general } \\
\text { weakness) }\end{array}$ & $\begin{array}{l}5727 \\
(12.39)\end{array}$ & $\begin{array}{l}8317 \\
(13.27)\end{array}$ & $\begin{array}{l}8688 \\
(12.16)\end{array}$ & $\begin{array}{l}9517 \\
(11.69)\end{array}$ & $\begin{array}{l}9369 \\
(11.79)\end{array}$ & $\begin{array}{l}27715 \\
(20.32)\end{array}$ & $\begin{array}{l}21315 \\
(20.44\end{array}$ \\
\hline Others : Specify & $(0.00)$ & $(0.00)$ & $(0.00)$ & $(0.00)$ & $(0.00)$ & $\begin{array}{l}2010 \\
(1.47)\end{array}$ & $\begin{array}{l}2011 \\
(1.93)\end{array}$ \\
\hline Others : Specify & $(0.00)$ & $(0.00)$ & $(0.00)$ & $(0.00)$ & $(0.00)$ & $\begin{array}{l}2010 \\
(1.47)\end{array}$ & $\begin{array}{l}2011 \\
(1.93)\end{array}$ \\
\hline Grand total & $\begin{array}{l}46208 \\
(100.00)\end{array}$ & $\begin{array}{l}62656 \\
(100.00)\end{array}$ & $\begin{array}{l}71473 \\
(100.00)\end{array}$ & $\begin{array}{l}81443 \\
(100.00)\end{array}$ & $\begin{array}{l}79484 \\
(100)\end{array}$ & $\begin{array}{l}136366 \\
(100.00)\end{array}$ & $\begin{array}{l}104285 \\
(100.00)\end{array}$ \\
\hline
\end{tabular}


and readmissions. An important observation is the focus of the health system on curative and mortality issues, whereas a rehabilitation-orientated health system would focus on morbidity and quality of life data (Bateman 2012).

\section{EXPENDITURE AND FINANCING OF REHABILITATION SERVICES}

Very little information could be found in the literature on actual expenditure distribution of related costs. Within the medical aid schemes R7 billion of R97 billion approximately $10-15 \%$ per annum is spent on allied health services (Occupational therapy, Physiotherapy, Biokinetics, Speech) and related needs (Medical Aid-press release 2012). In the public sector, no information on expenditure could be found in published literature. Thus proxy indicators such as staff and infrastructural support can only be used to give a sense of where the expenditure is spent. Seventeen percent (1040) of physiotherapists on the HPCSA register work in the public sector (NDoH 2013 and 21\% (794) of OTs. With Gauteng having the highest figures of personnel in public service followed by KwaZulu Natal and the lowest being in the Western Cape (HST 2013, DoH 2011).

An audit of the national health care facilities (Health Systems Trust 2013) reveals that only $6-20 \%$ of PHC facilities offer rehabilitation services. Occupational and physiotherapy services were 20 and $19 \%$ respectively. In hospitals, the onsite services are offered by $32-77 \%$ of facilities respectively (HST 2013). Furthermore, the current medical aid coverage in the country reveals that expenditure on health is disproportionate in the private and public sector with per person expenditure being four times higher in the private sector (R11150 vs. R2766) (Department of Health 2011a). It is important to align the distribution and the type of services to the burden of disease which would improve the country's health delivery and rehabilitation efforts.

\section{RECOMMENDATIONS Quadruple burden of disease} With regard to the rehabilitation professions response to the burden of disease, further studies and appropriate training should be done into the areas and fields of practice of all members of the professions. The shortage of therapists at appropriate levels needs to be addressed and engagement with fresh strategic approaches to this problem should be examined.

\section{Service delivery}

There is need for the re-examination of service delivery models from the level of district hospital to community health centre. A "one size fits all" is not the answer and the perennial shortages of therapists at all levels, calls for radical approaches to service delivery models. The delivery of service at these levels should perhaps respond to the call by the $\mathrm{PHC}$ reengineering to provide a service that is not discipline or specific programme based to one that is more holistic. Figure $\mathbf{3}$ gives a pictorial representation of the two models.

The provision of service in silos of physiotherapy, occupational therapy and speech therapy should be re-examined and shift towards the WHOs supermarket approach where the patient will obtain all rehabilitation services in a transdisciplinary manner (WHO 2012). This calls for a more concerted acceptance of a multidisciplinary health personnel (Davis 2006). Attrition of rehabilitation staff has not been fully studied. George et al (2012) reported a 15\% HIV/AIDS prevalence among professional staff and migration to be responsible for attrition (George et al 2012). Urban migration and emigration have been cited as reasons for therapist attrition but no national study could be found to support this. Training of rehabilitation personnel with appropriate skills for a tailor made system is important. The rehabilitation personnel at district level will require good generalist skills and specific skills for the community setting (Maleka and Franzsen 2008).

The NHI aims to promote innovative models of providing specialist care and a parallel to integrated working practices between GPs and hospital based specialists (Department of Health 2011a). Therapists could develop and test models of private-public partnerships that could be funded to produce the necessary evidence for larger roll out where the context lends itself to this model. Coupled with the need to examine service delivery models is the need to assess and improve the quality of management within the delivery of rehabilitation services. This includes interventions to improve waiting time, consistency of treatment, quality of treatment; meeting treatment needs and patient satisfaction are some of the issues that need to be examined.

\section{RESEARCH}

The time has come for rehabilitation professionals to examine their approach to research. As Mothabeng (2003) points out the need for increased clinical research and alignment with national needs is imperative. However, larger population based studies that can contribute to policy and clinical practice is urgently needed. The NDoH 2011 Research Summit Report outlined some important strengths, weaknesses

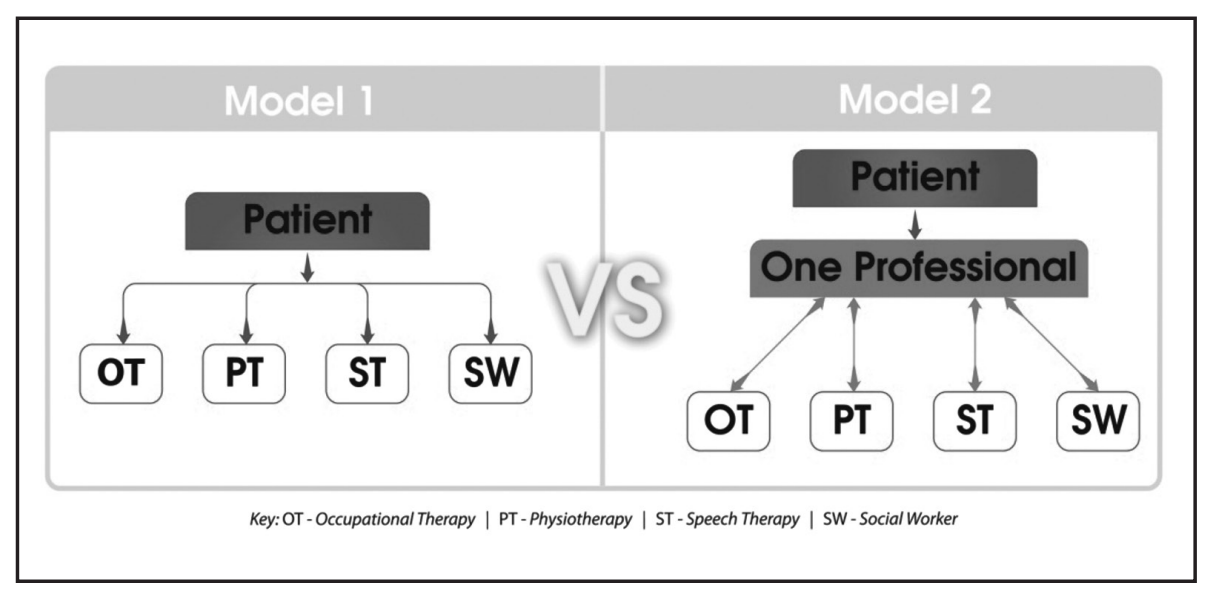

Figure 3: Models of service delivery - patient - therapist 
and opportunities with the current research agenda which rehabilitation professions should strive to build on where appropriate. Some strengths include existing research infrastructure robust surveillance systems and good internationally recognised literature in the areas of chronic disease and injury prevention and violence (Department of Health 2011b). Rehabilitation fraternity could possibly draw data collection systems that will add the dimension of morbidity and rehabilitation specific strengths in improving patient function and quality of life. Existing surveillance systems could include rehabilitation data that contribute to policy changes. Our current research agendas will contribute to appropriate measures and variables but as rehabilitation professionals it is important to engage and map a clear way forward. This could include enhancing the weaknesses that exist in the larger research agenda such as aging and inadequate numbers of researchers, limited funding, lack of national surveillance systems for morbidity data (e.g. cancer registers, quality of care and poor systems to translate data into policy and practice) (Department of Health 2011b). Opportunities such as the global focus on chronic non-communicable diseases and social determinants of health, and the WHO call to reduce deaths from non-communicable diseases by $2 \%$ per year should be examined.

\section{CONCLUSION}

The NHI calls for an examination of equitable service delivery. To do this, every profession including rehabilitation professions needs to examine their research, service delivery and its distribution financially and in terms of personnel, response to burden of disease and the quality of service provided.

\section{REFERENCES}

African National Congress 2010. “ANC General Council Additional Discussion Documents. Section 1: National health Insurance." ANC General Council Additional Discussion Documents. Section 1: National health Insurance. Pp 3-48. . Retrieved 18 April 2013, from http://www. anc.org.za/show.php?id=6013

Bateman C 2012 One size fits all' health policies crippling rural rehabilitation therapists. South African Medical Journal 102: 200-208

Bradshaw D, Groenewald P, Laubscher R, Nannan N, Nojilana B, Norman R, Pieterse D, Schneider M 2003. Initial Burden of Disease Estimates for South Africa, 2000. Cape Town, South African Medical Research Council

Davis S 2006 Rehabilitation:the use of theories and models in Practice Elsevier, Toronto

Department of Health 2010. Rehabilitation statistics collation project, Department of Health, Rehabilitation services

Department of Health 2011a. National Health Act,2003: Policy on National Health Insurance 554, Government Gazette (Government Printer): 3-32

Department of Health 2011b. Strengthening research for health, innovation and development in South Africa

Department of Health October 2011. Human Resources for Health (HRH) Strategy For The Health Sector - 2012/13 - 2016/17. DoH. Johannesburg

Econex 2009. South Africa's Burden of Disease. Econex. Stellenbosch4 pages. Retrieved 23 March 2013 from http://www.econex.co.za/index. php? option $=$ com_docman \& task $=\mathrm{doc}_{-}$ details\&gid $=43 \&$ Itemid $=60$

Frantz JM, Diener I, Jelsma J, 2011 Does the South African Physiotherapy Journal fulfill the needs of its constituency? A retrospective article review SA Journal of Physiotherapy 2011 Vol 67 No 3: 4-8

George G, Quinlan T, Reardon C, Aguilera J 2012 Where are we short and who are we short of? A review of human resources for health in South Africa. Health SA Gesondheid 17(1) 7 pages. Retrieved 23 March 2013, from http://www. hsag.co.za/index.php/HSAG/article/view/622

Health Systems Trust 2013. National health care facilities baseline audit- national summary report. Trust H. S.

Jelsma, J, De Weerdt, W, De Cock, P 2002 Disability Adjusted Life Years (DALYs) and rehabilitation. Disability and Rehabilitation 24: 378-382
Kleinert, S, Horton, R 2009. South Africa's health: departing to a better future? The Lancet 374:759-760.

Maleka, D, Franzsen, D 2008 Physiotherapy Services Required at Primary Health Care Level in Gauteng and Limpopo Provinces (Service Provider's Perspective Physiotherapists/Assistants). South Africa Journal of Physiotherapy 64: 1-7

Matsotso, M.P, Fryatt, R 2013. National Health Insurance: the first 18 months. In: Padarath A, English R, editors. South African Health Review 2012/13. Durban: Health Systems Trust.

Mothabeng, J 2003 An analysis of pedagogic research. South African Journal of Physiotherapy 62: $14-18$

Mothabeng, J 2006 Research and the physiotherapy profession in South Africa - Reflections on a pilot study. South African Journal of Physiotherapy 59: $9-15$

Norman R, Bradshaw D, Schneider M, Pieterse D, Groenewald, P 2006. Revised Burden of Disease Estimates for the Comparative Risk Factor Assessment, South Africa 2000. Methodological Note. Cape Town:, South African Medical Research Council.

WHO 2012. WHO Framework. Management for Health services delivery. WHO 